\title{
Effect of Acute Handball Training on Irisin, Leptin and Some Biochemical Parameters for Adolescence Handball Players
}

\author{
Aykut Dündar \\ Physical Education and Sports College, Adiyaman University, Turkey
}

Copyright $(2019$ by authors, all rights reserved. Authors agree that this article remains permanently open access under the terms of the Creative Commons Attribution License 4.0 International License

\begin{abstract}
This study aims to investigate the effect of acute handball training on the irisin, leptin, insulin and blood lipids. 19 male handball players, who are between 15-17, regularly train and play for Turkish Super Young League, have been volunteer for this research. All of the members of this research group are healthy and play handball for at least 3 years. Blood samples have been drawn from players before and after training (30 min. warming, $10 \mathrm{~min}$. stretching and $80 \mathrm{~min}$. handball training). Arithmetic average, standard deviation and frequency distribution techniques have been used for analyzing data as descriptive statistics. A significant change have been detected at total cholesterol, triglyceride, HDL, LDL, AST, ALT, irisin and leptin parameters but not at VLDL when the pre-test and post-test compared. It has been concluded that the blood lipid levels generally change by the training and acute exercise. However, the glucose level increases and insulin level decreases after exercise. According to results, an increase has been observed at irisin level but a decrease has been observed at leptin level during the exercise. Additionally, irisin and leptin interaction may occur in different ages and metabolisms. It has been suggested that irisin and leptin interactions should be investigated deeper for more comprehensive data.
\end{abstract}

Keywords Acute Exercise, Irisin, Leptin

\section{Introduction}

It is clear that exercise increases the physical relevance, affects the general health positively and plays an important role to prevent the body from illnesses. Body composition and biochemical parameters change due to the type, intensity and period of exercise [1-2].

Irisin is a thermogenic protein, which provides energy consuming by transforming the white lipid tissue to the brown [3]. Bostom and Ark have found a protein in 2012, which could prevent the body from metabolic illnesses and produced by skeleton muscle after exercise. Irisin forms after the hydrolyze of Fibronektin type III Alan 5 (FNDC5) protein by an unknown protease in skeleton muscles [3].

Leptin was found by Zhang and his friends, it is a cytokine like protein structured hormone which consists of 167 amino acids [4]. While insulin, glucocorticoids and prolactin stimulates the synthesis of leptin, thyroid hormones, growth hormone, somatostatin, free fatty acids, low temperature exposure and catecholamines inhibits leptin synthesis [5-6]. Strong effect of regular exercises on fatty acids and glucose, by dissolving fats from tissues, and the effect of leptin on increasing food intake and energy metabolism has brought up to agenda the investigation of relationship between leptin and exercises [7]. However, there are some reports, none of them have focused on handball payers and the literature needs to be enriched.

It is well known that the low-density lipoproteins (LDL) cholesterol, high density lipoprotein (HDL) cholesterol and triglycerides are the most common parameters to detect the change at the level of blood lipids. High LDL cholesterol indicates extreme level of lipids, which increases the risk of cardiovascular complications. HDL cholesterol transports lipids to liver for recycle and disposal. Thus, high level of HDL cholesterol shows a healthy cardiovascular system [8]. This study aims to evaluate the effect of acute exercise on irisin, leptin, insulin and blood lipids of adolescence handball players to investigate the effect of physical activity.

\section{Method}

\subsection{Participants}

19 adolescence (15-17) male handball players who are 
playing in Turkish Men Super Young League have been volunteer for this study. All participants are healthy and playing handball for at least 3 years. All participants and their parents have signed the informing form, which has been prepared according to Helsinki Declaration. The Adiyaman University Ethical Committee has been approved this study with 2017/7-1 approval number.

\subsection{Applied Measurements and Tests}

\subsubsection{Physical Measurements}

The ages of all participants have been saved after the id check. Body Mass Index (BMI) is the proportion of weight to the square of length $\left(\mathrm{kg} / \mathrm{m}^{2}\right)$. Body weight and BMI have been measured by Tanita BC-418 MA (Body Composition Analyzator) device [9]. Length of participants has been measured by mobile stadiometer.

$$
\text { Body Mass Index }\left(\text { BMI) }=\text { Weight } /(\text { length })^{2}\right.
$$

\subsubsection{Applied Training}

$30 \mathrm{~min}$. warming and $10 \mathrm{~min}$. stretching have been applied at the beginning of the training. $50 \mathrm{~min}$. general condition, technical and tactical training have been applied before $30 \mathrm{~min}$. high tempo training match. A low intensity stretching has been applied at the end.

\subsection{Detection of Blood Parameters}

$10 \mathrm{cc}$ blood samples have been drawn by injection from front arm vein of all participants before and after the training. Serum has been separated on centrifuge at 4000 rpm for $5 \mathrm{~min}$ and analyzed the laboratory of Adiyaman Government Hospital.

\subsection{Analysis of Data}

SPSS 15 suit of program was used to analyze the data. Arithmetic average, standard deviation, frequency distribution and paired sample $t$ test techniques have been used for analyzing data as descriptive statistics.

\section{Findings}

Frequencies, which belong to variables, maximum and minimum limits were reported on table 1 . According to table the participants' average age is 16.052 , average weight is 66.421 , length is 164.000 and average BMI is 23.089 (Table 1).

Table 1. Descriptive statistics (Body Mass Index, weight, Length, age) of participants

\begin{tabular}{|c|c|c|c|c|c|c|}
\hline & $\mathbf{N}$ & Minimum & Maximum & Average & \pm & SD \\
\hline Age (year) & 19 & 15.00 & 17.00 & 16.052 & \pm & 0.848 \\
\hline Weight $(\mathrm{kg})$ & 19 & 56.00 & 80.00 & 66.421 & \pm & 5.862 \\
\hline Length $(\mathrm{cm})$ & 19 & 156.00 & 172.00 & 164.000 & \pm & 4.690 \\
\hline BMI $\left(\mathrm{kg} / \mathrm{m}^{2}\right)$ & 19 & 20.10 & 24.80 & 23.089 & \pm & 1.090 \\
\hline
\end{tabular}

Glucose, insulin, total cholesterol, triglyceride, HDL, LDL, VLDL, AST, ALT, irisin and leptin levels of handball players have been detected before and after the acute exercise (Table 2). The difference between the pretest (60.631) and post-test (78.105) of glucose has been detected statistically significant (table 2, $\mathrm{p}<0.05$ ). A statistically significant difference has been calculated also for insulin (pre-test=13.744 and post-test=12.026). In case of pre-test (160.736) and post-test (141.526) of total cholesterol and pre-test (95.243) and post-test (82.384) of LDL, there are statistically significant decreases have been observed (table 2, $\mathrm{p}<0.05$ ). Significant increases have been observed between the pre-test (97.842) and post-test (126.263) of triglyceride and pre-test (43.389) and post-test (49.046) of HDL (table 2, $\mathrm{p}<0.05$ ). There are increases between the pre-tests and post-tests of AST (pre-test $=19.203$, post-test $=22.958$ ), ALT (pre-test $=19.263$, post-test $=26.021$ ) and VLDL (pre-test $=81.552$, post-test $=92.210$ ) but the increases are statistically significant for only AST and ALT but not for VLDL. It has been observed from the table 2 that there is a significant increase between the pre-test (698.334) and post-test (1344.495) of irisin; and there is a significant decrease between the pre-test (2.277) and post-test (1.559) of leptin (table 2, $\mathrm{p}<0.05$ ). 
Table 2. Participants' Glucose, Insulin, Total Cholesterol, Triglyceride, HDL, LDL, VLDL, AST, ALT, Irisin, Leptin test results

\begin{tabular}{|c|c|c|c|c|c|c|}
\hline Parameter & Test & Average & & SD & $\mathbf{t}$ & $\mathbf{p}$ \\
\hline \multirow{2}{*}{ Glucose } & Pre-test & 60.631 & \pm & 12.280 & \multirow{2}{*}{-7.157} & \multirow{2}{*}{$0.000^{*}$} \\
\hline & Post-test & 78.105 & \pm & 11.850 & & \\
\hline \multirow{2}{*}{ Insulin } & Pre-test & 13.744 & \pm & 0.623 & \multirow{2}{*}{9.053} & \multirow{2}{*}{$0.000^{*}$} \\
\hline & Post-test & 12.026 & \pm & 0.734 & & \\
\hline \multirow{2}{*}{ Total Cholesterol } & Pre-test & 160.736 & \pm & 22.863 & \multirow{2}{*}{3.677} & \multirow{2}{*}{$0.002^{*}$} \\
\hline & Post-test & 141.526 & \pm & 25.069 & & \\
\hline \multirow{2}{*}{ Triglyceride } & Pre-test & 97.842 & \pm & 29.341 & \multirow{2}{*}{-3.181} & \multirow{2}{*}{$0.005^{*}$} \\
\hline & Post-test & 126.263 & \pm & 36.877 & & \\
\hline \multirow{2}{*}{ HDL } & Pre-test & 43.389 & \pm & 6.791 & \multirow{2}{*}{-4.519} & \multirow{2}{*}{$0.000^{*}$} \\
\hline & Post-test & 49.046 & \pm & 8.195 & & \\
\hline \multirow{2}{*}{ LDL } & Pre-test & 95.243 & \pm & 16.133 & \multirow{2}{*}{5.693} & \multirow{2}{*}{$0.000^{*}$} \\
\hline & Post-test & 82.384 & \pm & 13.985 & & \\
\hline \multirow{2}{*}{ VLDL } & Pre-test & 81.552 & \pm & 78.342 & \multirow{2}{*}{-0.5161} & \multirow{2}{*}{0.612} \\
\hline & Post-test & 92.210 & \pm & 81.314 & & \\
\hline \multirow{2}{*}{ AST } & Pre-test & 19.203 & \pm & 4.225 & \multirow{2}{*}{-6.097} & \multirow{2}{*}{$0.000 *$} \\
\hline & Post-test & 22.958 & \pm & 4.551 & & \\
\hline \multirow{2}{*}{ ALT } & Pre-test & 19.263 & \pm & 6.104 & \multirow{2}{*}{-5.183} & \multirow{2}{*}{$0.000^{*}$} \\
\hline & Post-test & 26.021 & \pm & 6.776 & & \\
\hline \multirow{2}{*}{ Irisin } & Pre-test & 698.334 & \pm & 237.700 & \multirow{2}{*}{-6.650} & \multirow{2}{*}{$0.000^{*}$} \\
\hline & Post-test & 1344.495 & \pm & 385.043 & & \\
\hline \multirow{2}{*}{ Leptin } & Pre-test & 2.277 & \pm & 1.165 & \multirow{2}{*}{6.573} & \multirow{2}{*}{$0.000^{*}$} \\
\hline & Post-test & 1.559 & \pm & 1.096 & & \\
\hline
\end{tabular}

${ }^{*} \mathrm{p}<0.05$ level statistically significant

\section{Discussion}

The effect of acute handball training on plasma irisin, leptin and other parameters during acute physical activity has been studied in this study. Pre-test/post-test model has been applied in this study.

There are statistically significant differences between the pre-tests and post-tests of both glucose and insulin $(p<0.05)$. According to the results, acute exercise decreases the insulin level and increases the glucose level. While the glucose oxidation increases rapidly, the muscle glycogen stores consumes during the high intensity exercises. Glucose intake from circulation system also increases. If there is enough glycogen in liver stores, an equilibrium establishes between the glucose production in liver and peripheral usage and the glucose level stabilized in normal range [10].

Çinar et al. have been reported that, after regular trainings the glucose level of taekwondo sporters has increased (90.70 micIU/ml while they are in rest) [11]. Cicioglu et al. have reported a study, which focuses on the effect of exercise on the blood parameters which are related with blood gases and glucose consumption. Participants have been undergone to bicycle ergometry test at maximum workload $(60 \mathrm{rpm})$ with maximum oxygen consumption and it has been concluded that increase at glucose level and decrease at insulin level were statistically significant [12]. Aydin et al. have reported that while the insulin hormone level of participants was $7.72 \mathrm{micIU} / \mathrm{ml}$ before the aerobic exercise, it has been decreased to 4.42 micIU/mlafter the exercise [13]. All these reports are in harmony with our study.

According to obtained results, it has been concluded that, there are statistically significant results for cholesterol, triglyceride, HDL, LDL, AST, ALT parameters but there is not any statistically significant result for VLDL even the value increases. The effect of acute exercise may be a reason for this result. In a recent study, the cholesterol level of a group of rugby player has been detected as $177.1 \pm$ $25.3 \mathrm{mg} / \mathrm{dl}$ before the camp period and $155.2 \pm 16.7 \mathrm{mg} / \mathrm{dl}$ after the camp period [13]. In another study, which is about sedentarian males, it has been reported that maximum heart rate was $60 \%$ and total cholesterol level has not changed [14]. Kraus et al. have reported that after 24 weeks exercise triglyceride levels increased $28.4 \mathrm{mg} / \mathrm{dl}$ [15]. However Donovan et al. have claimed that triglyceride level increased $0.12 \mathrm{mmol} / \mathrm{L}$ [16]. It has been observed in another study that there is an increase at the triglyceride levels, which have been detected before and after the exercise [14]. There are many studies, which reports 
significant increases at HDL level after exercise [16-19]. According to a study, exercise decreased the LDL levels of females about $0.2 \mathrm{mmol} / \mathrm{L}[20]$. Kraus et al. have reported that the LDL levels of participants have decreased 1.9 $\mathrm{mg} / \mathrm{dl}$ [15]. Cengiz et al. have concluded that the LDL levels of participants have decreased significantly [21]. Rosmarin et al. reported that the levels of ALT and AST increase with the intensity and duration of exercise [22]. Similarly, Mashiko et al. and $\mathrm{Su}$ et al. have reported a significant increase at ALT and AST levels [13-23]. Our study supports the literature because of similar results with recent studies.

Post-test results of our study have shown a significant increase when compared with pre-test results. Bostom et al. have reported that FNDC5 mRNA has increased at the cranium of rats and human after exercise. Contrary to the first study of Bostom et al., no significant increases have been observed after chronic exercise [3]. Thus, it has been concluded that irisin may be an acute exercise hormone. It has been observed that the irisin level has been increased shortly after the exercise [24]. Yoshifumi et al. have been reported that short-term and high intensity exercises increase the density of serum irisin more than the exercises, which are low intensity and long-term even the results are not statistically significant [25]. Huh et al. have reported that while irisin level has not change during chronic vibration exercise, it increases after acute exercise on sedentarian males [24].

A group of non-diabetic males have been applied aerobic exercise for 10 weeks and their blood and muscle biopsy samples have been taken before and after exercise. It has been reported that the level of irisin in the circulation duplicated (26). This increase has been explained by increase at sympathetic activation [27] and it has also concluded that the irisin causes an increase at energy consumption [28]. Our study is important because of its similarity to these results.

According to the obtained results, it has been concluded that the Leptin levels have decreased significantly, when compared with pre-tests. It is very well known that exercise changes the energy equilibrium by increasing the energy consumption and causes a decrease at fat mass. That is why so many studies carried out to investigate the effect of exercise on leptin. It has been concluded that exercise effect leptin by sympathoadrenal system [29].

Short-term $(\leq 60 \mathrm{~min})$ exercises do not have or have a little effect on serum leptin levels [30-31]. But long-term exercises $(>60 \mathrm{~min})$ causes a decrease at serum leptin level [32-33-34]. Essig et al. have observed that concentration of leptin did not change short after and 24 hours later than exercise but it decreased $30 \%$ after 48 hours at $70 \%$ of VO2max [32]. Leal-Cerro et al., who have reported that significant changes at energy consumption may change leptin levels, have concluded that after consumption of $2800 \mathrm{cal}$, leptin level starts to decrease [35]. Decrease of leptin has been explained by the rhythm of day or hemoconcentration mechanism
[36-37]. All above studies support our results.

\section{Result}

It has been concluded that the blood lipid levels generally change by the training and acute exercise. However, the glucose level increases and insulin level decreases after exercise. According to results, an increase has been observed at irisin level but a decrease has been observed at leptin level during the exercise. These results are compatible with literature. Additionally, irisin and leptin interaction may occur in different ages and metabolisms. It has been suggested that irisin and leptin interactions should be investigated deeper for more comprehensive data.

\section{REFERENCES}

[1] Ball K, Owen N, Salmon J, Bauman A, Gore C. Associations of physical activity with body weight and fat in men and women. International Journal of Obesity. 2001; 25(6):914

[2] Pate RR, Pratt M, Blair SN, Haskell WL, Macera CA, Bouchard C, et al. Physical activity and public health: a recommendation from the Centers for Disease Control and Prevention and the American College of Sports Medicine. Jama. 1995;273(5):402-7.

[3] Boström P, Wu J, Jedrychowski MP, Korde A, Ye L, Lo JC, et al. A PGC1- $\alpha$-dependent myokine that drives brown-fat-like development of white fat and thermogenesis. Nature. 2012; 481(7382):463.

[4] Zhang Y, Proenca R, Maffei M, Barone M, Leopold L, Friedman JM. Positional cloning of the mouse obese gene and its human homologue. Nature. 1994; 372(6505):425.

[5] Aslan K, Serdar Z, Tokullugil HA. Multifonksiyonel hormon: leptin. Uludağ Üniversitesi Tıp Fakültesi Dergisi. 2004;30(2):113-8

[6] Frühbeck G. Intracellular signalling pathways activated by leptin. Biochemical Journal. 2006; 393(1):7-20.

[7] Unal M, Unal DO, Salman F, Baltaci AK, Mogulkoc R. The relation between serum leptin levels and max VO2 in male patients with type I diabetes and healthy sedentary males. Endocrine research. 2004; 30(3):491-8.

[8] Carroll MD, Kit BK, Lacher DA. Total and high-density lipoprotein cholesterol in adults; National Health and Nutrition Examination Survey, 2009-2010. 2012.

[9] Güney E, Özgen G, Saraç F, Yılmaz C, Kabalak T. Biyoelektrik impedans yöntemi ile obezite tanısında kullanılan diğer yöntemlerin karşılaştırılması. 2003.

[10] Gökdemir cak, cicioğlu i. Aerobik ve anaerobik egzersiz sonrasi insülin ve kan glikoz değerlerinin incelenmesi. Spor bilimleri dergisi. 2000; 11(1):47-55.

[11] Cinar V, Polat Y, Mogulkoc R, Nizamlioglu M, Baltaci AK. The effect of magnesium supplementation on glucose and 
insulin levels of tae-kwan-do sportsmen and sedentary subjects. Pakistan journal of pharmaceutical sciences. 2008; 21(3).

[12] Cicioğlu i, onay m. Yüksek yoğunluktaki egzersizin güreşçilerde kan gazlari ve glukoz kullanimi ile ilgili kan parametreleri üzerine etkisi/the effects of high intensity exercise on blood gases and s. Journal of physical education and sport sciences. 2002;4(3).

[13] Mashiko T, Umeda T, Nakaji S, Sugawara K. Effects of exercise on the physical condition of college rugby players during summer training camp. British Journal of Sports Medicine. 2004; 38(2):186-90.

[14] Hubinger LM, Mackinnon LT. The acute effect of $30 \mathrm{~min}$ of moderate exercise on high density lipoprotein cholesterol in untrained middle-aged men. European Journal of Applied Physiology and Occupational Physiology. 1992; 65(6):555-60.

[15] Kraus WE, Houmard JA, Duscha BD, Knetzger KJ, Wharton $\mathrm{MB}, \mathrm{McCartney} \mathrm{JS}$, et al. Effects of the amount and intensity of exercise on plasma lipoproteins. New England Journal of Medicine. 2002; 347(19):1483-92.

[16] O'Donovan G, Owen A, Bird SR, Kearney EM, Nevill AM, Jones DW, et al. Changes in cardiorespiratory fitness and coronary heart disease risk factors following $24 \mathrm{wk}$ of moderate-or high-intensity exercise of equal energy cost. Journal of Applied Physiology. 2005; 98(5):1619-25.

[17] Arslan E, Kelle M, Baylan Y, Diken H, Atmaca M, Tümer C, et al. Sporcularda plazma lipid düzeylerinin kendi aralarında ve kontrollerle karşılaştırılması. Dicle Tıp Dergisi (Journal Of Medical School). 2001; 28(1):23-34.

[18] Çolakoğlu F, Şenel Ö. Sekiz haftalık aerobik egzersiz programının sedanter orta yaşlı bayanların vücut kompozisyonu ve kan lipidleri üzerindeki etkileri. Ankara Üniversitesi Beden Eğitimi ve Spor Bilimleri Dergisi. 2003; 1(1):56-61

[19] Şekeroğlu MR, Recep Aslan MT, Kara M. Sedanter erkeklerde akut ve programl egzersizin serum apolipoproteinleri ve lipitleri üzerine etkileri'. Genel TiP Derg. 1997; 7(1).

[20] LeMura LM, von Duvillard SP, Andreacci J, Klebez JM, Chelland SA, Russo J. Lipid and lipoprotein profiles, cardiovascular fitness, body composition, and diet during and after resistance, aerobic and combination training in young women. European Journal of Applied Physiology. $2000 ; 82(5-6): 451-8$.

[21] Cengiz Ş, Dündar A, Çınar V, Pala R. Effect of short term match program on certain blood lipids of football players. 2013.

[22] Koutedakis Y, Raafat A, Sharp N, Rosmarin M, Beard M, Robbins S. Serum enzyme activities in individuals with different levels of physical fitness. The Journal of Sports Medicine and Physical Fitness. 1993; 33(3):252-7.

[23] Su Y-C, Lin C-J, Chen K-T, Lee S-M, Lin J-S, Tsai C-C, et al. Effects of huangqi jianzhong tang on hematological and biochemical parameters in judo athletes. ACTA Pharmacologica sinica. 2001;22(12):1154-8.

[24] Huh JY, Mougios V, Skraparlis A, Kabasakalis A,
Mantzoros CS. Irisin in response to acute and chronic whole-body vibration exercise in humans. Metabolism. 2014; 63(7):918-21.

[25] Tsuchiya Y, Ando D, Goto K, Kiuchi M, Yamakita M, Koyama K. High-intensity exercise causes greater irisin response compared with low-intensity exercise under similar energy consumption. The Tohoku Journal of Experimental Medicine. 2014; 233(2):135-40.

[26] Besse-Patin A, Montastier E, Vinel C, Castan-Laurell I, Louche K, Dray C, et al. Effect of endurance training on skeletal muscle myokine expression in obese men: identification of apelin as a novel myokine. International Journal of Obesity. 2014; 38(5):707.

[27] Scalzo RL, Peltonen GL, Giordano GR, Binns SE, Klochak AL, Paris HL, et al. Regulators of human white adipose browning: evidence for sympathetic control and sexual dimorphic responses to sprint interval training. PloS one. 2014; 9(3):e90696.

[28] Swick AG, Orena S, O'Connor A. Irisin levels correlate with energy expenditure in a subgroup of humans with energy expenditure greater than predicted by fat free mass. Metabolism. 2013;62(8):1070-3.

[29] Torjman MC. On the delayed effects of exercise on leptin: more questions than answers. Nutrition. 2001; 17(5):420-2.

[30] Torjman M, Zafeiridis A, Paolone A, Wilkerson C, Considine R. Serum leptin during recovery following maximal incremental and prolonged exercise. International Journal of Sports Medicine. 1999; 20(07):444-50.

[31] Weltman A, Pritzlaff C, Wideman L, Considine R, Fryburg $\mathrm{D}$, Gutgesell $\mathrm{M}$, et al. Intensity of acute exercise does not affect serum leptin concentrations in young men. Medicine and Science in Sports and Exercise. 2000; 32(9):1556-61.

[32] Essig DA, Alderson NL, Ferguson MA, Bartoli WP, Durstine JL. Delayed effects of exercise on the plasma leptin concentration. Metabolism-Clinical and Experimental. 2000; 49(3):395-9.

[33] Olive JL, Miller GD. Differential effects of maximal-and moderate-intensity runs on plasma leptin in healthy trained subjects. Nutrition. 2001; 17(5):365-9.

[34] Zaccaria M, Ermolao A, Roi G, Englaro P, Tegon G, Varnier M. Leptin reduction after endurance races differing in duration and energy expenditure. European Journal of Applied Physiology. 2002;87(2):108-11.

[35] Leal-Cerro A, Garcia-Luna PP, Astorga R, Parejo J, Peino R, Dieguez C, et al. Serum leptin levels in male marathon athletes before and after the marathon run. The Journal of Clinical Endocrinology \& Metabolism. 1998;83(7):2376-9.

[36] Kraemer R, Acevedo E, Synovitz L, Hebert E, Gimpel T, Castracane V. Leptin and steroid hormone responses to exercise in adolescent female runners over a 7-week season. European journal of applied physiology. 2001;86(1):85-91.

[37] Kraemer R, Johnson L, Haltom R, Kraemer G, Hebert E, Gimpel T, et al. Serum leptin concentrations in response to acute exercise in postmenopausal women with and without hormone replacement therapy. Proceedings of the Society for Experimental Biology and Medicine. 1999; 221(3):171-7. 